\title{
Gambaran Masalah Psikososial pada Remaja dengan Thalassemia Mayor dan Diabetes Mellitus Tipe-1
}

Bernie Endyarni Medise, ${ }^{1}$ Naela Fadhila, ${ }^{1}$ Tjhin Wiguna, ${ }^{2}$ Zakiudin Munasir, ${ }^{1}$ Jose R. Batubara, ${ }^{1}$ Pustika Amalia Wahidiyat, ${ }^{1}$ H.F. Wulandari, ${ }^{1}$ Rosalina Dewi Roeslani ${ }^{1}$

${ }^{1}$ Departemen Ilmu Kesehatan Anak, ${ }^{2}$ Departemen Ilmu Kesehatan Jiwa Fakultas Kedokteran Universitas Indonesia, Jakarta

Latar belakang. Thalassemia dan diabetes mellitus tipe-1 (DM tipe-1) merupakan penyakit kronik yang banyak didapatkan pada anak dan remaja di Indonesia. Adanya penyakit kronik pada remaja dapat berisiko meningkatkan terjadinya masalah psikososial 2-6 kali dibandingkan populasi sehat. Masalah psikososial pada remaja sulit dikenali sehingga perlu dilakukan evaluasi secara rutin. The strengths and difficulties questionnaire (SDQ) adalah instrumen yang praktis dan mudah digunakan untuk mendeteksi masalah tersebut. Tujuan. Mengetahui besaran masalah psikososial pada remaja dengan penyakit kronik di RS. Cipto Mangunkusumo, Jakarta. Metode. Desain potong lintang pada 140 remaja (100 thalassemia mayor dan 40 DM tipe-1), usia 10-18 tahun. Subyek diminta untuk mengisi kuesioner SDQ (laporan mandiri).

Hasil. Prevalensi total skor abnormal pada remaja thalassemia mayor adalah 8\%, dan DM tipe-1 adalah 15\%. Tidak ada skor abnormal pada aspek perilaku pro-sosial kedua penyakit, dan aspek hubungan dengan teman sebaya DM tipe-1. Tidak didapatkan perbedaan bermakna antara diagnosis penyakit, jenis kelamin, dan tingkat pendidikan subyek pasien DM terhadap luaran hasil SDQ.

Kesimpulan. Masalah psikososial lebih banyak didapatkan pada remaja DM tipe-1 dibandingkan thalassemia mayor. Sari Pediatri 2020;22(2):83-91

Kata kunci: penyakit kronik, psikososial, remaja, SDQ

\section{Psychosocial Problems in Adolescents with Thalassemia Major and Type- 1 Diabetes Mellitus}

Bernie Endyarni Medise, ${ }^{1}$ Naela Fadhila, ${ }^{1}$ Tjhin Wiguna, ${ }^{2}$ Zakiudin Munasir, ${ }^{1}$ Jose R. Batubara, ${ }^{1}$ Pustika Amalia Wahidiyat, ${ }^{1}$ H.F. Wulandari, ${ }^{1}$ Rosalina Dewi Roeslani ${ }^{1}$

Background. Thalassaemia and type-1 diabetes mellitus (T1DM) are highly prevalent chronic diseases in children and adolescents in Indonesia. The presence of chronic diseases will increase the risk of psychosocial problems by 2-6 times compared with healthy populations. Psychosocial problems in adolescents are difficult to recognize, so routine evaluation is necessary. The Strengths and Difficulties Questionnaire (SDQ) is a practical and user-friendly screening instrument to detect the problem.

Objective. Knowing the magnitude of psychosocial problems in adolescents with chronic diseases at Cipto Mangunkusumo Hospital, Jakarta.

Methods. A cross-sectional design study was conducted on a total of 140 adolescents, consisting of 100 thalassaemia major and 40 T1DM, age 10-18 years. Adolescents were asked to fill SDQ self-report form.

Result. Prevalence of abnormal total difficulties score is $8 \%$ in thalassaemia major and $15 \%$ in T1DM. There were no abnormal scores on the pro-social subscale of both diseases, and peer problems subscale of the DM type-1 group. No correlation between diagnosis of disease, sex, and education background of T1DM on SDQ result.

Conclusion. Results indicate a higher presence of psychosocial problems in adolescents with T1DM than thalassaemia major. Sari Pediatri 2020;22(2):83-91

Key words: chronic disease, adolescent, psychosocial, SDQ

\footnotetext{
Alamat korespondensi: Bernie Endyarni Medise. Departemen Ilmu Kesehatan Anak Fakultas Kedokteran Universitas Indonesia, Jakarta. Jl Salemba Raya Jakarta Pusat. Email: bernie.medise@yahoo.com
} 
$\mathrm{P}$ ada satu dekade terakhir, telah terjadi pergeseran pola penyakit pada anak dan remaja dari penyakit infeksi menjadi penyakit kronik. ${ }^{1}$ Thalassemia dan DM tipe-1 merupakan bagian dari penyakit kronik yang banyak ditemui pada anak dan remaja di dunia, termasuk Indonesia. Data Pusat Thalassemia Rumah Sakit Cipto Mangunkusumo (RSCM) menunjukkan bahwa sampai dengan awal tahun 2018 terdapat 1723 pasien thalassemia dengan distribusi usia 10-18 tahun. ${ }^{2}$ Sementara data registri nasional dari Unit Kerja Koordinasi (UKK) Endokrinologi Anak dan Remaja Ikatan Dokter Anak Indonesia (IDAI) mendapatkan 1170 kasus anak DM tipe-1 hingga tahun 2016. ${ }^{3}$

Remaja merupakan suatu fase transisi dari anak menuju dewasa. Selain perubahan bentuk fisis, juga terjadi proses perkembangan maturasi psikologis, yaitu bagaimana mengatasi masalah dan menerima respons dari lingkungan. Masalah timbul ketika remaja harus dihadapkan dengan berbagai kesulitan dari aspek medis, bersamaan dengan proses membentuk identitas, membangun kepercayaan diri, menjalin hubungan dengan teman dan lawan jenis. Memiliki penyakit kronik dapat merupakan faktor stres yang dapat meningkatkan risiko 2-6 kali lipat lebih besar terjadinya masalah psikososial dibandingkan anak sehat. ${ }^{4,5,6}$

Masalah emosi dan perilaku pada remaja dengan penyakit kronik belum banyak dilaporkan dalam kepustakaan Indonesia karena evaluasi belum dilakukan secara rutin. Hal ini dapat dimaklumi karena gejalanya kadang sulit dikenali, kecuali terdapat perubahan perilaku signifikan. ${ }^{6-8}$ Penelitian oleh Glazebrook $\mathrm{dkk}^{4}$ menyatakan bahwa hanya sebesar $25 \%$ kasus yang mampu dikenali oleh dokter spesialis anak sehingga terjadi kesenjangan antara tingginya risiko gangguan kejiwaan dengan rendahnya angka pelayanan kesehatan jiwa pada kelompok usia ini. ${ }^{9}$

Pada penelitian ini gambaran masalah psikososial dievaluasi menggunakan instrumen The strengths and difficulties questionnaire (SDQ). Instrumen ini telah digunakan secara luas, mudah dikerjakan, dan telah diterjemahkan dan diadaptasi ke dalam bahasa Indonesia. Instrumen ini mampu mendeteksi masalah psikososial dengan nilai sensitivitas $85 \%$ dan spesivisitas $80 \%$. $^{10,11}$

\section{Metode}

Penelitian merupakan studi deskriptif analitik dengan desain potong lintang dan dilakukan di Poli Hemato-
Onkologi Anak RSCM, Poli Endokrinologi Anak RSCM, Ruang Transfusi Thalassemia RSCM, dan Ruang Rawat Inap Anak Gedung A RSCM pada Juni 2018. Kriteria inklusi adalah remaja (10-18 tahun) dengan thalassemia mayor atau DM tipe-1 dengan lama diagnosis sekurang-kurangnya tiga bulan, yang melakukan kontrol rutin di RSCM. Kriteria eksklusi adalah remaja yang dirinya atau orangtuanya menolak menandatangani informed. Data diambil secara konsekutif hingga jumlah sampel penelitian terpenuhi. Penelitian ini telah memperoleh kelaikan etik dari Komite Etik Penelitian Kesehatan FKUI RSCM, Jakarta.

Subyek dan orangtua dijelaskan mengenai penelitian menggunakan formulir SDQ laporan mandiri untuk remaja usia 11-17 tahun dan orang tua untuk remaja di bawah 11 tahun. Total skor yang menggambarkan kesulitan, dibagi menjadi normal, borderline, dan abnormal. Skor prososial merupakan aspek kekuatan remaja. Subyek dengan skor SDQ abnormal akan dirujuk ke Poli Psikiatri Anak dan Remaja, Departemen Ilmu Kesehatan Jiwa FKUIRSCM untuk evaluasi lanjutan, sedangkan subyek dengan skor SDQ normal atau borderline akan dipantau dan dilakukan evaluasi ulangan berkala di Poli Tumbuh Kembang Pediatri Sosial RSCM.

Data diolah menggunakan perangkat lunak SPSS 22.0. Variabel bebas meliputi jenis penyakit, jenis kelamin, tingkat pendidikan subyek, dan lama diagnosis. Variabel tergantung adalah lima aspek dalam SDQ, yaitu perilaku pro-sosial, masalah emosional, masalah perilaku, hiperaktivitas, masalah hubungan dengan teman sebaya. Analisis data dilakukan dengan uji kai kuadrat saat membandingkan proporsi. Bila syarat tidak terpenuhi digunakan metode alternatif Fisher atau Kolmogorov-smirnov. Kemaknaan secara statistik dilakukan dengan menetapkan nilai $\mathrm{p}<0,05$.

\section{Hasil}

Terdapat total 140 subyek remaja terdiri atas 100 subyek kelompok thalassemia mayor dan 40 subyek kelompok DM tipe-1. Tidak terdapat perbedaan bermakna antara jumlah subyek lelaki dan perempuan, dengan rasio 1:1.5. Mayoritas subyek berada pada rentang usia 10-14 tahun, dengan mean dan median berusia 14 tahun di kedua kelompok penyakit. Seluruh subyek yang bersekolah berada dalam tingkat 
pendidikan sesuai usia, namun terdapat 12 subyek thalassemia mayor dan 2 subyek DM tipe-1 mengalami putus sekolah. Karakteristik subyek penelitian tertera pada Tabel 1.

Delapan subyek thalassemia mayor dan 6 subyek DM tipe-1 memiliki total skor abnormal. Komposisi skor abnormal terbanyak didapatkan pada aspek masalah emosional dan masalah perilaku. Tidak ada subyek dari kedua kelompok yang memiliki skor abnormal pada aspek perilaku pro-sosial; dan aspek hubungan dengan teman sebaya (DM tipe-1). Tidak didapatkan perbedaan bermakna luaran hasil SDQ pada kedua kelompok penyakit $(p>0,05)$. Hasil penilaian SDQ subyek penelitian tertera pada Tabel 2.

Kedua kelompok penyakit dengan total skor SDQ abnormal didominasi oleh perempuan dan suybek bersekolah. Subyek lelaki lebih banyak mengalami masalah perilaku dibandingkan perempuan, yaitu $50 \%$ pada subyek thalassemia mayor dan $62.5 \%$ pada subyek DM tipe-1 62,5\%. Tidak didapatkan perbedaan bermakna antara jenis kelamin subyek dengan luaran hasil SDQ yang didapat ( $p>0,05)$ (Tabel 3.)

Penilaian skor abnormal di kedua kelompok penyakit mayoritas didapatkan pada subyek yang bersekolah, baik pada penilaian total skor maupun skor tiap aspek dalam SDQ. Pada subyek putus sekolah di kelompok thalassemia mayor, dua subyek memiliki masalah pada aspek perilaku, dan satu subyek memiliki masalah pada aspek hubungan dengan teman sebaya. Tidak didapatkan perbedaan bermakna antara tingkat pendidikan subyek dengan luaran hasil SDQ yang didapat ( $p>0.05)$. Hasil penilaian SDQ berdasarkan tingkat pendidikan subyek tertera pada Tabel 4 .

\section{Pembahasan}

Penelitian ini adalah studi pertama yang memperlihatkan gambaran masalah emosi dan perilaku remaja penyakit kronik menggunakan SDQ di Indonesia. Penelitian sebelumnya menggunakan instrumen lain, seperti child behavior checklist (CBCL), pediatric symptom checklist 17 (PSC-17), dan kuesioner masalah mental emosional (KMME). Pemilihan SDQ sebagai modalitas pada penelitian ini memiliki konsekuensi, yaitu hanya dapat memberikan gambaran masalah secara umum (tidak spesifik) sehingga keluhan, kekhawatiran, dan kesulitan yang sesungguhnya dihadapi oleh remaja tidak tergambar, dan menjadi keterbatasan pada penelitian ini.

Tabel 1. Karakteristik subyek penelitian

\begin{tabular}{|c|c|c|c|c|}
\hline \multirow{2}{*}{$\begin{array}{l}\text { Karakteristik } \\
\text { Jenis kelamin }\end{array}$} & \multicolumn{2}{|c|}{$\begin{array}{c}\text { Thalassemia mayor } \\
\mathrm{n}=100(100 \%)\end{array}$} & \multicolumn{2}{|c|}{$\begin{array}{c}\text { DM tipe-1 } \\
\mathrm{n}=40(100 \%)\end{array}$} \\
\hline & & & & \\
\hline Lelaki & 40 & $(40,0)$ & 15 & $(37,5)$ \\
\hline Perempuan & 60 & $(60,0)$ & 25 & $(62,5)$ \\
\hline \multicolumn{5}{|l|}{ Usia (tahun) } \\
\hline $10-14$ & 58 & $(58,0)$ & 21 & $(52,5)$ \\
\hline $15-17$ & 39 & $(39,0)$ & 17 & $(42,5)$ \\
\hline$\geq 17$ & 3 & $(3,0)$ & 2 & $(5,0)$ \\
\hline \multicolumn{5}{|l|}{ Alamat } \\
\hline Jakarta & 66 & $(66,0)$ & 23 & $(57,5)$ \\
\hline Bogor & 13 & $(13,0)$ & 5 & $(12,5)$ \\
\hline Depok & 6 & $(6,0)$ & 5 & $(12,5)$ \\
\hline Tangerang & 5 & $(5,0)$ & 2 & $(5,0)$ \\
\hline Bekasi & 5 & $(5,0)$ & 4 & $(10,0)$ \\
\hline Lain-lain & 5 & $(5,0)$ & 1 & $(2,5)$ \\
\hline \multicolumn{5}{|l|}{ Pendidikan anak } \\
\hline Belum sekolah & 0 & (0) & 0 & (0) \\
\hline Sekolah & 88 & $(88,0)$ & 38 & $(40,0)$ \\
\hline Putus sekolah & 12 & $(12,0)$ & 2 & $(5,0)$ \\
\hline
\end{tabular}


Pada penelitian ini penilaian SDQ menggunakan satu sumber, yaitu remaja di atas 11 tahun. Sebaiknya, SDQ dinilai dari dua sumber, yaitu remaja dan orangtua/guru. ${ }^{12,13} \mathrm{Hal}$ ini untuk menghindari adanya bias pengisian data, terkait perbedaan cara pandang dan evaluasi penilaian antara remaja dengan orang dewasa sehingga berpengaruh terhadap hasil penelitian.

Pada hasil penelitian terlihat bahwa banyak remaja DM tipe-1 tidak lagi melanjutkan pengobatan di RSCM, melainkan ke rumah sakit tipe B atau C terdekat dari tempat tinggal sehingga jumlah subjek DM tipe-1 hanya terkumpul 40 subjek. Hal ini secara tidak langsung memberikan gambaran perbaikan penataan sistem rujukan di Indonesia.

Tidak adanya perbedaan yang bermakna pada rasio subyek lelaki dan perempuan di kedua kelompok penyakit sesuai dengan pola pewarisan sifat. Thalassemia diturunkan secara autosomal resesif dan bukan melalui kromosom seks. Pada DM tipe-1 juga tidak didapatkan perbedaan bermakna jenis kelamin terhadap insiden penyakit, meskipun kebanyakan penyakit autoimun mayoritas terjadi pada perempuan. ${ }^{14}$ Berbeda dengan onset gejala thalassemia mayor yang umumnya terjadi di dua tahun pertama kehidupan, onset gejala pada DM tipe-1 memuncak pada dua periode, yaitu usia 4-6 tahun dan saat awal terjadinya masa pubertas (10-14 tahun). ${ }^{15}$ Sebanyak $45 \%$ pasien DM tipe- 1 memiliki onset gejala di bawah usia 10 tahun. ${ }^{16}$ Onset penyakit pada subyek penelitian ini berkisar antara usia 4-17 tahun dengan mean 9 tahun.

Anak dan remaja dengan penyakit kronik memiliki peningkatan risiko emosi dan perilaku 2-6 kali lipat dibandingkan populasi sehat. ${ }^{4-6}$ Risiko terbesar dimiliki oleh kelainan yang melibatkan sistem saraf pusat (SSP), yaitu meliputi epilepsi, palsi serebral, dan tumor intrakranial. ${ }^{17} \mathrm{Hal}$ itu disebabkan oleh mekanisme

Tabel 2. Hasil Penilaian SDQ pada subyek penelitian

\begin{tabular}{|c|c|c|c|c|c|}
\hline & & ia mayor & & pe-1 & \\
\hline & & & & & Nilai $\mathrm{p}$ \\
\hline & & & & & \\
\hline Normal & 84 & $(84,0)$ & 26 & $(65,0)$ & \\
\hline Borderline & 8 & $(8,0)$ & 8 & $(20,0)$ & \\
\hline Abnormal & 8 & $(8,0)$ & 6 & $(15,0)$ & \\
\hline Perilaku pro-sosial & & & & & $0,44^{\mathrm{b}}$ \\
\hline Normal & 93 & $(93,0)$ & 39 & $(97,5)$ & \\
\hline Borderline & 7 & $(7,0)$ & 1 & $(2,5)$ & \\
\hline Abnormal & 0 & (0) & 0 & $(0)$ & \\
\hline Masalah emosional & & & & & $0,76^{\mathrm{b}}$ \\
\hline Normal & 80 & $(80,0)$ & 27 & $(67,5)$ & \\
\hline Borderline & 10 & $(10,0)$ & 6 & $(15,0)$ & \\
\hline Abnormal & 10 & $(10,0)$ & 7 & $(17,5)$ & \\
\hline Masalah perilaku & & & & & $0,59^{\mathrm{b}}$ \\
\hline Normal & 87 & $(87,0)$ & 29 & $(72,5)$ & \\
\hline Borderline & 7 & $(7,0)$ & 3 & $(7,5)$ & \\
\hline Abnormal & 6 & $(6,0)$ & 8 & $(20,0)$ & \\
\hline Hiperaktivitas & & & & & $0,99^{\mathrm{b}}$ \\
\hline Normal & 88 & $(88,0)$ & 33 & $(82,5)$ & \\
\hline Borderline & 7 & $(7,0)$ & 2 & $(5,0)$ & \\
\hline Abnormal & 5 & $(5,0)$ & 5 & $(12,5)$ & \\
\hline Hubungan teman sebaya & & & & & $1,00^{\mathrm{b}}$ \\
\hline Normal & 78 & $(78,0)$ & 32 & $(80,0)$ & \\
\hline Borderline & 19 & $(19,0)$ & 8 & $(20,0)$ & \\
\hline Abnormal & 3 & $(3,0)$ & 0 & $(0)$ & \\
\hline
\end{tabular}

${ }^{a}$ Uji Fisher, ${ }^{b}$ Uji Kolmogorov-Smirnoff; p: nilai probabilitas 
Bernie Endyarni Medise dkk: Gambaran masalah psikososial pada remaja dengan thalassemia mayor dan DM tipe-1

Tabel 3. Hasil penilaian SDQ berdasarkan jenis kelamin

\begin{tabular}{|c|c|c|c|c|c|c|c|c|c|c|}
\hline & \multicolumn{5}{|c|}{ Thalassemia mayor } & \multicolumn{5}{|c|}{ DM tipe-1 } \\
\hline & \multicolumn{2}{|c|}{$\begin{array}{c}\text { Lelaki } \\
\mathrm{n}=40(100 \%)\end{array}$} & \multicolumn{2}{|c|}{$\begin{array}{c}\text { Perempuan } \\
\mathrm{n}=60(100 \%)\end{array}$} & \multirow[t]{2}{*}{$\begin{array}{c}\text { Nilai } \\
\mathrm{p}\end{array}$} & \multicolumn{2}{|c|}{$\begin{array}{c}\text { Lelaki } \\
\mathrm{n}=15(100 \%)\end{array}$} & \multicolumn{2}{|c|}{$\begin{array}{c}\text { Perempuan } \\
\mathrm{n}=25(100 \%)\end{array}$} & \multirow[t]{2}{*}{$\begin{array}{c}\text { Nilai } \\
\mathrm{p}\end{array}$} \\
\hline \multicolumn{9}{|c|}{ Total skor SDQ } & & \\
\hline Normal & 32 & $(38,1)$ & 52 & $(61,9)$ & $1,00^{\mathrm{b}}$ & 12 & $(46,2)$ & 14 & $(53,8)$ & $0,65^{b}$ \\
\hline Borderline & 4 & $(50,0)$ & 4 & $(50,0)$ & & 1 & $(12,5)$ & 7 & $(87,5)$ & \\
\hline Abnormal & 4 & $(50,0)$ & 4 & $(50,0)$ & & 2 & $(33,3)$ & 4 & $(66,7)$ & \\
\hline \multicolumn{11}{|c|}{ Perilaku pro-sosial } \\
\hline Normal & 37 & $(39,8)$ & 56 & $(60,2)$ & $1,00^{\mathrm{a}}$ & 15 & $(38,5)$ & 24 & $(61,5)$ & $1,00^{\mathrm{a}}$ \\
\hline Borderline & 3 & $(42,9)$ & 4 & $(57,1)$ & & 0 & (0) & 1 & $(100,0)$ & \\
\hline Abnormal & 0 & (0) & 0 & (0) & & 0 & (0) & 0 & (0) & \\
\hline \multicolumn{11}{|c|}{ Masalah emosional } \\
\hline Normal & 34 & $(42,5)$ & 46 & $(57,5)$ & $0,85^{\mathrm{b}}$ & 11 & $(40,7)$ & 16 & $(59,3)$ & $1,00^{\mathrm{b}}$ \\
\hline Borderline & 5 & $(50,0)$ & 5 & $(50,0)$ & & 2 & $(33,3)$ & 4 & $(66,7)$ & \\
\hline Abnormal & 1 & $(10,0)$ & 9 & $(90,0)$ & & 2 & $(28,6)$ & 5 & $(71,4)$ & \\
\hline \multicolumn{11}{|c|}{ Masalah perilaku } \\
\hline Normal & 34 & $(39,1)$ & 53 & $(60,9)$ & $1,00^{\mathrm{b}}$ & 10 & $(34,5)$ & 19 & $(65,5)$ & $0,79^{\mathrm{b}}$ \\
\hline Borderline & 3 & $(42,9)$ & 4 & $(57,1)$ & & 0 & (0) & 3 & $(100,0)$ & \\
\hline Abnormal & 3 & $(50,0)$ & 3 & $(50,0)$ & & 5 & $(62,5)$ & 3 & $(37,5)$ & \\
\hline \multicolumn{11}{|c|}{ Hiperaktivitas } \\
\hline Normal & 36 & $(40,9)$ & 52 & $(59,1)$ & $1,00^{\mathrm{b}}$ & 12 & $(36,4)$ & 21 & $(63,6)$ & $1,00^{\mathrm{b}}$ \\
\hline Borderline & 2 & $(28,6)$ & 5 & $(71,4)$ & & 1 & $(50,0)$ & 1 & $(50,0)$ & \\
\hline Abnormal & 2 & $(40,0)$ & 3 & $(60,0)$ & & 2 & $(40,0)$ & 3 & $(60,0)$ & \\
\hline \multicolumn{11}{|c|}{ Hubungan teman sebaya } \\
\hline Normal & 32 & $(41,0)$ & 46 & $(59,0)$ & $1,00^{\mathrm{b}}$ & 12 & $(37,5)$ & 20 & $(62,5)$ & $1,00^{\mathrm{b}}$ \\
\hline Borderline & 8 & $(42,1)$ & 11 & $(57,9)$ & & 3 & $(37,5)$ & 5 & $(62,5)$ & \\
\hline Abnormal & 0 & (0) & 3 & $(100)$ & & 0 & (0) & 0 & (0) & \\
\hline
\end{tabular}

${ }^{\mathrm{a} U j i}$ Fisher, ${ }^{\mathrm{b}}$ Uji Kolmogorov-Smirnoff; p: nilai probabilitas

kontrol perilaku yang terletak pada SSP, sedangkan pada kelainan non-neurologi, masalah emosi dan perilaku muncul sebagai respons adaptasi seseorang terhadap beban yang ditimbulkan oleh penyakit tersebut. Belum ada penelitian sebelumnya yang secara langsung membandingkan masalah psikososial antara remaja thalassemia dengan DM tipe-1.

Pada penelitian ini didapatkan bahwa prevalensi masalah emosi dan perilaku lebih tinggi didapatkan pada remaja kelompok DM tipe-1 (15\%) dibandingkan dengan remaja kelompok thalassemia mayor (8\%). Berbagai alasan dapat dipikirkan menjadi penyebab. ${ }^{18,19}$ Tata kelola DM tipe-1 memiliki pengaruh besar terhadap kehidupan, terutama perubahan besar gaya hidup. Dimulai dari pengaturan makan, pemberian terapi, dan evaluasi berkala, yang harus diterapkan sepanjang waktu, baik di dalam maupun di luar rumah, pada lingkungan keluarga maupun pada saat bersosialisasi dengan teman. Hal tersebut tidak mudah karena melibatkan dukungan dan kerja sama dari semua pihak. Pada masa menuju dewasa, remaja juga dituntut untuk memiliki kemandirian padahal tata kelola DM tipe-1 itu sendiri merupakan program yang kompleks, selain itu mereka juga harus melakukan tindakan invasif secara mandiri dan mengatasi nyeri. Apabila aturan tersebut dilanggar, dampaknya dapat langsung dirasakan sehingga menambah beban psikologis akan kekhawatiran terhadap komplikasi penyakit dan kematian.

Berbeda dengan intensitas terapi yang dihadapi remaja DM tipe-1, remaja thalassemia mayor dihadapkan dengan prosedur transfusi darah sekurangkurangnya 8-12 kali per tahun. Prosedur transfusi dilakukan di fasilitas kesehatan (bukan di tempat umum) dan diawasi oleh tenaga medis. Tidak terdapat perubahan besar pada gaya hidup keseharian, kecuali 
Bernie Endyarni Medise dkk: Gambaran masalah psikososial pada remaja dengan thalassemia mayor dan DM tipe-1

Tabel 4. Hasil penilaian SDQ berdasarkan tingkat pendidikan subyek

\begin{tabular}{|c|c|c|c|c|c|c|c|c|c|c|}
\hline & \multicolumn{5}{|c|}{ Thalassemia mayor } & \multicolumn{5}{|c|}{ DM tipe-1 } \\
\hline & \multicolumn{2}{|c|}{$\begin{array}{c}\text { Sekolah } \\
\mathrm{n}=88(100 \%)\end{array}$} & \multicolumn{2}{|c|}{$\begin{array}{c}\text { Putus sekolah } \\
\mathrm{n}=12(100 \%)\end{array}$} & \multirow[t]{2}{*}{$\begin{array}{l}\text { Nilai } \\
\mathrm{p}\end{array}$} & \multicolumn{2}{|c|}{$\begin{array}{c}\text { Sekolah } \\
\mathrm{n}=38(100 \%)\end{array}$} & \multicolumn{2}{|c|}{$\begin{array}{l}\text { Putus sekolah } \\
\mathrm{n}=2 \\
(100 \%)\end{array}$} & \multirow[t]{2}{*}{$\begin{array}{c}\text { Nilai } \\
\mathrm{p}\end{array}$} \\
\hline \multicolumn{9}{|c|}{ Total skor SDQ } & & \\
\hline Normal & 75 & $(89,3)$ & 1 & $(6,2)$ & $1,00^{\mathrm{b}}$ & 15 & $(93,8)$ & 1 & $(6,2)$ & $1,00^{\mathrm{b}}$ \\
\hline Borderline & 6 & $(75,0)$ & 0 & $(0,0)$ & & 4 & $(100,0)$ & 0 & $(0,0)$ & \\
\hline Abnormal & 7 & $(87,5)$ & 0 & $(0,0)$ & & 2 & $(100,0)$ & 0 & $(0,0)$ & \\
\hline \multicolumn{11}{|c|}{ Perilaku pro-sosial } \\
\hline Normal & 81 & $(87,1)$ & 12 & $(12,9)$ & $0,59^{a}$ & 37 & $(94,9)$ & 2 & $(5,1)$ & $1,00^{\mathrm{a}}$ \\
\hline Borderline & 7 & $(100,0)$ & 0 & (0) & & 1 & $(100,0)$ & 0 & (0) & \\
\hline Abnormal & 0 & (0) & 0 & (0) & & 0 & (0) & 0 & (0) & \\
\hline \multicolumn{11}{|c|}{ Masalah emosional } \\
\hline Normal & 71 & $(88,8)$ & 9 & $(11,2)$ & $0,99^{\mathrm{b}}$ & 25 & $(92,6)$ & 2 & $(7,4)$ & $0,98^{b}$ \\
\hline Borderline & 7 & $(70,0)$ & 3 & $(30,0)$ & & 6 & $(100,0)$ & 0 & (0) & \\
\hline Abnormal & 10 & $(100,0)$ & 0 & (0) & & 7 & $(100,0)$ & 0 & (0) & \\
\hline \multicolumn{11}{|c|}{ Masalah perilaku } \\
\hline Normal & 78 & $(89,7)$ & 9 & $(10,3)$ & $0,98^{\mathrm{b}}$ & 27 & $(93,1)$ & 2 & $(6,9)$ & $0,99^{\mathrm{b}}$ \\
\hline Borderline & 6 & $(85,7)$ & 1 & $(14,3)$ & & 3 & $(100,0)$ & 0 & (0) & \\
\hline Abnormal & 4 & $(66,7)$ & 2 & $(33,3)$ & & 8 & $(100,0)$ & 0 & (0) & \\
\hline \multicolumn{11}{|c|}{ Hiperaktivitas } \\
\hline Normal & 78 & $(88,6)$ & 10 & $(11,4)$ & $1,00^{\mathrm{b}}$ & 31 & $(93,9)$ & 2 & $(6,1)$ & $1,00^{\mathrm{b}}$ \\
\hline Borderline & 5 & $(71,4)$ & 2 & $(28,6)$ & & 2 & $(100,0)$ & 0 & (0) & \\
\hline Abnormal & 5 & $(100,0)$ & 0 & (0) & & 5 & $(100,0)$ & 0 & (0) & \\
\hline \multicolumn{11}{|c|}{ Hubungan teman sebaya } \\
\hline Normal & 71 & $(91,0)$ & 7 & $(9,0)$ & $0,67^{\mathrm{b}}$ & 30 & $(93,8)$ & 2 & $(6,2)$ & $1,00^{\mathrm{b}}$ \\
\hline Borderline & 15 & $(78,9)$ & 4 & $(21,1)$ & & 8 & $(100,0)$ & 0 & (0) & \\
\hline Abnormal & 2 & $(66,7)$ & 1 & $(33,3)$ & & 0 & (0) & 0 & (0) & \\
\hline
\end{tabular}

${ }^{a}$ Uji Fisher, ${ }^{b}$ Uji Kolmogorov-Smirnoff; p: nilai probabilitas

tuntutan akan konsumsi terapi kelasi besi. Dampak akibat ketidakpatuhan akan terapi kelasi besi pun juga tidak langsung dirasakan.

Prevalensi masalah emosi dan perilaku remaja thalassemia yang didapat jauh lebih rendah dibandingkan dengan penelitian Behdani $\mathrm{dkk}^{20}$ yang melaporkan prevalensi sebesar 26\%. Penelitian Aydin $\mathrm{dkk}^{21}$ menyatakan bahwa $80 \%$ dari remaja thalassemia memiliki sekurangnya satu kelainan kejiwaan. Berbagai faktor berkontribusi terhadap masalah tersebut, tetapi studi oleh Wahab $\mathrm{dkk}^{22}$ di Malaysia melaporkan bahwa faktor stres utama dikaitkan dengan kekhawatiran akan pendidikan, citra diri yang buruk, pemikiran akan masa depan (kemampuan mendapatkan pekerjaan dan pasangan hidup), dan bersosialisasi.

Hasil pada penelitian ini sejalan dengan penelitian oleh Di Palma $\mathrm{dkk}^{23}$ yang melaporkan bahwa remaja thalassemia mayor dapat memiliki gambaran psikologis dan perkembangan sosial yang baik. Penelitian Brady $\mathrm{dkk}^{24}$ melaporkan bahwa faktor yang dapat menurunkan risiko depresi pada pasien thalassemia adalah hubungan yang erat dengan tenaga kesehatan dan sesama pasien thalassemia lainnya, dukungan dari ibu, dan pemberian kelasi besi secara oral. Hal tersebut sangat wajar mengingat hampir setiap 2-3 minggu pasien harus menghabiskan waktu di rumah sakit.

Tidak didapatkan perbedaan bermakna antara jenis kelamin dan tingkat pendidikan remaja thalassemia mayor dengan luaran hasil SDQ. Perbedaan bermakna pernah dilaporkan oleh Mednick $\mathrm{dkk}^{25}$ yang menyatakan tingginya kejadian depresi dan cemas pada perempuan dan hal tersebut sejalan dengan meningkatnya usia. Pada penelitian tersebut subyek adalah kelompok usia late adolescence dan dewasa 
sehingga tidak relevan untuk dibandingkan pada penelitian ini. prevalensi masalah emosi dan perilaku pada remaja DM tipe-1 di penelitian ini lebih rendah dibandingkan dengan penelitian sebelumnya. Namun begitu, komposisi minimal skor abnormal pada aspek perilaku pro-sosial dan hubungan dengan teman sebaya adalah sama. ${ }^{26,27}$ Perilaku pro-sosial yang baik dari studi ini dapat memperbaiki stigma gambaran negatif remaja DM tipe-1 yang ada selama ini, sejalan dengan hasil yang ditunjukkan pada aspek hubungan teman sebaya.

Pada penelitian ini tidak didapatkan perbedaan bermakna antara jenis kelamin dan tingkat pendidikan remaja DM tipe-1 dengan luaran hasil SDQ. Hasil berbeda dikemukakan oleh Al-Khurinej ${ }^{45}$ yang melaporkan tingkat pendidikan pasien adalah faktor yang memiliki kaitan erat dengan aspek perilaku prososial. Sementara Alkhairi $\mathrm{dkk}^{27}$ melaporkan kaitan erat antara remaja perempuan DM tipe-1 dengan masalah perilaku, dan remaja lelaki DM tipe-1 dengan masalah emosi.

Terdapat beberapa penelitian yang menghubungkan aspek psikologis pasien DM tipe-1 dengan fungsi neurokognitif. Suatu meta-analisis tahun 2009 melaporkan bahwa anak dengan DM tipe-1 memiliki kelemahan kognitif ringan dan memengaruhi keseluruhan fungsi intelektual. ${ }^{28}$ Dininya awitan penyakit merupakan prediktor terkuat yang memengaruhi performa neuropsikologis, dalam hal ini atensi dan fungsi eksekutif. ${ }^{29}$ Dikatakan bahwa tingginya kadar gula darah pada penderita DM tipe-1 dapat mengganggu mielinisasi dan regulasi neurotransmitter pada saat periode perkembangan otak sehingga mengurangi kemampuan anak untuk mengatasi berbagai masalah, termasuk masalah psikososial..$^{30}$

Secara keseluruhan dapat dikatakan bahwa prevalensi masalah psikososial remaja thalassemia mayor dan DM tipe-1 di Indonesia, khususnya di RSCM sebagai pusat rujukan nasional adalah rendah. Hal ini menggambarkan keberhasilan tata kelola penyakit di RSCM sudah cukup baik. Perhatian terhadap aspek psikososial sangat besar, terlihat dari maraknya berbagai kegiatan yang difasilitasi RSCM dan komunitas thalassemia atau DM. Pertukaran informasi dan edukasi tidak hanya diberikan secara formal dan tatap muka, melainkan juga melalui grup diskusi kecil, sosial media, dan forum daring.

Pada penelitian ini sebanyak delapan remaja thalassemia mayor dan enam remaja DM tipe-1 akan dirujuk ke Poli Psikiatri Anak dan Remaja RSCM untuk mendapatkan tata laksana di bidang kesehatan jiwa. Masalah emosi dan perilaku memiliki dampak yang besar terutama terhadap prognosis penyakit dasar dan kualitas hidup. Insidens gangguan mental dikatakan meningkat dua kali lipat pada pasien yang tidak mendapatkan tata laksana adekuat. ${ }^{31}$ Pada remaja dengan skor SDQ borderline di kedua kelompok penyakit, edukasi, konseling dan evaluasi kembali masalah harus sangat ditekankan guna mencegah berkembangnya derajat keparahan masalah.

Konseling pada remaja thallasemia mayor diadakan berkala selama 45 menit, setiap dua kali per bulan, selama satu tahun, dengan mengikutsertakan orangtua. Konseling kadang dilakukan bersamaan pada saat transfusi atau pengecekan darah rutin. Pada pengamatan selama satu tahun, didapatkan hasil bahwa sebanyak 90\% subyek memiliki kepatuhan yang baik terhadap terapi kelasi besi, walaupun hubungannya dengan kadar ferritin tidak bermakna secara statistik. ${ }^{21}$ Manfaat yang sama diperlihatkan juga pada DM tipe-1. Adanya konseling terbukti dapat memperbaiki kontrol glikemik pasien, ditandai dengan penurunan kadar HbA1c. ${ }^{32}$ Orangtua harus diikutsertakan karena karena kunci keberhasilan kelola DM tipe-1 sangat dipengaruhi oleh semua pihak, terutama keluarga.

American Association for Diabetes (ADA) ${ }^{33}$ dan International Society for Pediatric and Adolescent Diabetes (ISPAD) ${ }^{34}$ merekomendasikan skrining depresi dilakukan setiap tahun pada remaja DM tipe-1 yang berusia di atas sepuluh tahun. Tidak ada instrumen tertentu, waktu konseling dan instrumen evaluasi yang direkomendasikan pada pedoman tersebut.

\section{Kesimpulan}

Mayoritas subyek penelitian ini adalah perempuan, mayoritas rentang usia 10-14 tahun (early adolescence), dan menempuh pendidikan sekolah. Prevalens masalah emosi dan perilaku berdasarkan SDQ laporan mandiri menunjukkan total skor abnormal $8 \%$ pada subyek thalassemia mayor; dan 15\% pada subyek DM tipe-1. Masalah terbanyak yang dihadapi adalah pada aspek emosional dan perilaku di kedua kelompok penyakit. Berdasarkan hasil ini, evaluasi masalah emosi dan perilaku pada remaja dengan thalassemia mayor dan DM tipe-1 hendaknya dilakukan berkala (setiap tahun), sehingga dapat menjaring, mengevaluasi lebih rinci, dan memberikan tata laksana adekuat di bidang psikososial. 
Bernie Endyarni Medise dkk: Gambaran masalah psikososial pada remaja dengan thalassemia mayor dan DM tipe-1

\section{Daftar pustaka}

1. Burns KH, Casey PH, Lyle RE, Bird TM, Fussell JJ, Robbins JM. Increasing prevalence of medically complex children in US hospitals. Pediatrics 2010;126:638-46.

2. Pusat Thalassemia RSUPN Dr. Cipto Mangunkusumo. Registri pasien thalassemia anak dan dewasa 2007-2018. Jakarta: Pusat Thalassemia RSUPN Dr. Cipto Mangunkusumo; 2018.

3. UKK Endokrinologi Anak dan Remaja Ikatan Dokter Anak Indonesia. Konsensus nasional pengelolaan diabetes mellitus tipe-1 pada anak dan remaja. Jakarta: Badan Penerbit Ikatan Dokter Anak Indonesia; 2015.

4. Glazebrook C, Hollis C, Heussler H, Goodman R, Coates L. Detecting emotional and behavioural problems in paediatric clinics. Child Care Health Dev 2003;29:141-9.

5. Hysing M, Elgen I, Gillberg C, Lundervold AJ. Emotional and behavioural problems in subgroups of children with chronic illness: results from a large-scale population study. Child Care Health Dev 2009;35:527-33.

6. Hysing M, Elgen I, Gillberg C, Lie SA, Lundervold AJ. Chronic physical illness and mental health in children: results from a large-scale population study. J Child Psychol Psychiatry 2007;48:785-92.

7. Campbell JM, Cardona L. The consultation and liaison processes to pediatrics. Dalam: Martin A, Volkmar FR, penyunting. Lewis's child and adolescent psychiatry: a comprehensive textbook. Edisi ke-4. Philadelphia: Lippicott Williams and Wilkins; 2007.h.912-21.

8. Costello EJ, Edelbrock CS. Detection of psychiatric disorders in pediatric primary care: a preliminary report. J Am Acad Child Psychiatry 1985;24:771-4.

9. Lavigne JV, Binns HJ, Christoffel KK, Rosenbaum D, Arend $\mathrm{R}$, Smith K, dkk. Behavioral and emotional problems among preschool children in pediatric primary care: prevalence and pediatricians' recognition. Pediatrics 1993;91:649-55.

10. Hagglof B. Psychological reaction by children of various ages to hospital care and invasive procedures. Acta Pediatr Suppl 1999;431:72-8.

11. De Giacomo A, Lamanna AL, Craig F, Santoro N, Goffredo $S$, Cecinati V. The SDQ in Italian clinical practice: evaluation between three outpatient groups compared. Riv Psichiatr 2012;47:400-6.

12. Becker A, Hagenberg N, Roessner V, Woerner W, Rothenberger A. Evaluation of the self-reported SDQ in a clinical setting: do self-reports tell us more than ratings by adult informants? Eur Child Adolesc Psychiatry 2004;13:17-24.

13. Erhart M, Ellert U, Kurth B, Ravens-Sieberer U. Measuring adolescents' HRQoL via self reports and parent proxy reports: an evaluation of the psychometric properties of both versions of the KINDL-R instrument. Health Qual Life Outcomes 2009;7:1-12.

14. Dabelea D, Mayer-Davis EJ, Saydah S, Imperatore G, Linder B, Divers J, dkk. Prevalence of type 1 and type 2 diabetes among children and adolescents from 2001 to 2009. JAMA 2014;311:1778-86.

15. Felner EI, Klitz W, Ham M, Lazaro AM, Stastny P, Dupont B, $\mathrm{dkk}$. Genetic interaction among three genomic regions creates distinct contributions to early- and late-onset type 1 diabetes mellitus. Pediatr Diabetes 2005;6:213-5.

16. Writing Group for the SEARCH for Diabetes in Youth Study Group, Dabelea D, Bell RA, D’Agostino RB Jr, Imperatore G, Johansen JM, dkk. Incidence of diabetes in youth in the United States. JAMA 2007;297:2716-23.

17. Seidel UP, Chadwick OF, Rutter M. Psychological disorders in crippled children. A comparative study of children with and without brain damage. Dev Med Child Neurol 1975;17;563-73.

18. King KM, King PJ, Nayar R, Wilkes S. Perceptions of adolescent patients of the "lived experience" of type 1 diabetes. Diabetes Spectr 2017;30:23-35.

19. Lehmkuhl HD, Merlo LJ, Devine K, Gaines J, Storch EA, Silverstein JH, dkk. Perceptions of type 1 diabetes among affected youth and their peers. J Clin Psychol Med Settings 2009;16:209-15.

20. Behdani F, Badiee Z, Hebrani P, Moharreri F, Badiee AH, Hajivosugh N, dkk. Psychological aspects in children and adolescents with major thalassemia: a case-control study. Iran J Pediatr 2015;25:1-8.

21. Aydin B, Yaprak I, Akarsu D, Okten N, Ulgen M. Psychosocial aspects and psychiatric disorders in children with thalassemia major. Acta Paediatr Jpn 1997;39:354-7.

22. Wahab JA, Naznin M, Nora MZ, Suzanah AR, Zulaiha M, Faszrul ARA, dkk. Thalassaemia: a study on the perception of patients and family members. Med J Malaysia 2011;66:32634.

23. Di Palma A, Vullo C, Zani B, Facchini A. Psychosocial integration of adolescents and young adults with thalassemia major. Ann N Y Acad Sci 1998;850:355-60.

24. Brady AMB. Chronic illness in childhood and adolescence: a longitudinal exploration of co-occurring mental illness (disertasi). London: Queen Mary University of London, 2017.

25. Mednick L, Yu S, Trachtenberg F, Xu Y, Kleinert DA, Giardina PJ. Symptoms of depression and anxiety in patients with thalassemia: prevalence and correlates in the thalassemia longitudinal cohort. Am J Hematol 2010;85:802-5.

26. Al-Khurinej A. Emotional and behavioral problems among diabetic children. Digest of Middle East Studies 2007;16:1-11.

27. Alkhairi E, AlAgha AE, Alasmari A, Khan A, Hijazi N, Subahi $\mathrm{Y}, \mathrm{dkk}$. The prevalence of psychological and behavioral changes 
among children and adolescents with diabetes in Makkah, Saudi Arabia. Curr Pediatr Res 2018; 22:9-15.

28. Naguib JM, Kulinskaya E, Lomax CL, Garralda E. Neurocognitive performance in children with type 1 diabetes: a meta-analysis. J Pediatr Psychol 2009;34:271-82.

29. Gaudieri PA, Chen R, Greer TF, Holmes CS. Cognitive function in children with type 1 diabetes. Diabetes Care 2008;31:1892-7.

30. Schiffrin A. Psychosocial issues in pediatric diabetes. Curr Diab Rep 2001;1:33-40.

31. Compas BE, Jaser SS, Dunn MJ, Rodriguez EM. Coping with chronic illness in childhood and adolescence. Annu Rev Clin Psychol 2012. 27;8:455-80.

32. Ashraff S, Siddiqui MA, Carline TE. The psychosocial impact of diabetes in adolescents: a review. Oman Med J 2013;28:15962.

33. Silverstein J, Klingensmith G, Copeland K, Plotnick L, Kaufman F, Laffel L, dkk. Care of children and adolescents with type 1 diabetes: a statement of the American Diabetes Association. Diabetes Care 2005;28:186-212.

34. Delamater AM. Psychological care of children and adolescents with diabetes. Pediatr Diabetes 2009;10:175-84. 